\title{
Retrospection of Innate Dyes as Chromophores in Dye-Sensitized Solar Cells
}

\author{
*Divya Jyoti and Ruchika Seth \\ Department of Physics, University College, India
}

Submission: July 13, 2017; Published: July 14, 2017

*Corresponding author: Divya Jyoti, Department of Physics, University College, Jaito Distt, Faridkot, pin-151202, Punjab, India, Tel: 9780011007; Email: divyabathla17@gmail.com

\begin{abstract}
In the present course of study, deliberate investigation of natural dyes versus synthetic dyes in dye-sensitized solar cells (DSSCs) has been undergone through. Although quoted efficiency values of artificial dyes like N7 dye, black dye and N719 dye etc. is efficiently higher than natural ones such as turmeric, rosella, sweet potato leaf and blue pea etc. Yet the latter meet the fundamental aim of DSSC i.e. low cost to performance ratio. Also considered dyes cause no environment threat, easily extractable, abundant and safe. Several methods to improve the performance of these innate dyes have been explored. Parameters viz. pH level of extract, extraction method, extracting temperature, multilayer configurations and usage with nanostructures can be considered as a great step to reach the higher value of output. Among natural dyes root of maharanga bi color herb, mangosteen pericarp etc. have proved their candidature as best anchoring choromophores in dyesensitized solar cells.
\end{abstract}

Keywords: Natural dyes; Mangosteen pericarp; Maharanga bi color herb

\section{Introduction}

Due to peak demand of environmental benign energy, dyesensitized solar cells have attracted a great deal of attention of researchers. In 1873, Herman Vogel [1] quoted that a few organic dyes could cause an enhancement in the green and red response of photographic films made of silver halide. The mechanism involved the transfer of electron or energy from the chromophore to the silver halide grain which is semiconducting. This spectral sensitization formed the basis for photography. Photovoltaic cells have also been known for a longer time. The initial was designed by E. Becquerel [2] in 1839 by using copper oxide or silver halide coated metal electrodes dipped in an electrolyte solution. On the other hand, modern solar cells are a more recent development in the first developed by D. Chapin, G. Pearson and Paul Rappaport at Bell Labs [3]. These cells consisted of a p-n junction which marks the barrier between electron and hole majority regions. Electrons and holes created through the absorption of light in silicon diffuse at in the n-doped and p-doped materials and are eventually combine at the junction. This $\mathrm{p}-\mathrm{n}$ junction is formed by a process which resembles that used by the semiconductor industry to manufacture integrated circuits and computer chips. Potentially more cost effective technologies, which use thin films of such materials as amorphous silicon deposited on glass, are under development [4].
This process is very costly, so researchers explored alternative low cost sensitization processes in solar cells. Preliminary work was done by Meier et al. [5]. Then in 1991, a Swiss research group combined several concepts to produce a low cost solar cell having efficiency $7 \%[6,7]$. The cell, which is called a dye- sensitized solar cell (DSSC), is remarkable in that it resembles natural photosynthesis as it uses an organic dye to absorb light and harness solar energy. It is one of a new class of devices which are called molecular electronic devices [8]. To fabricate the cell, a solution of particles of $\mathrm{TiO}_{2}$ was deposited directly on conductive glass by a process similar to that used in painting. The film was heated to form a porous $\mathrm{TiO}_{2}$ morphology which resembles a thin sponge. This was used as a photo anode and was dipped into a solution of a dye [9].

A layer of the dye molecules can be adsorbed onto the layer of $\mathrm{TiO}_{2}$ via the carboxylic groups and acts as the fundamental absorber of sunlight. To synthesize the final cell, a drop of liquid electrolyte containing iodide is placed on the film to permeate into the pores of the semiconductor. A counter electrode of a thin layer of platinum or carbon deposited on conducting glass is placed on top. Then this sandwich type structure is ready to be illuminated by sunlight through the $\mathrm{TiO}_{2}$ support. Since the dye layer is thin, the excited electrons produced from 
light absorption in the dye can be transported into the $\mathrm{TiO}_{2}$. In contrast to conventional Si or Ga As solar cells, charge carrier transport in the light absorbing compound is not relevant to the cell design; therefore it becomes quite easier to tailor its properties to enhance the output of the cell.

In the present paper, role of natural dyes is discussed with regards to optimum cost versus performance. Although natural dyes lag behind synthetic dyes in the race of efficiency by being employed as choromophores in DSSCs, yet these open the gates to a vast research field.

\section{Natural Dyes}

A dye should possess a phenolic group that is responsible for its anchoring to the semiconducting surface. Among natural dyes anthocyanins forms a group of naturally occurring phenolic compound creditworthy for the color of many flowers, fruits and vegetables. The most vernacular anthocynidins (anthocynanins without glycoside group) found in flowers are pelargonidin (orange), cyanidin (orange-red), peoridin (orangered), deliphinidin (blue-red), petonidin (blue-red) and melvidin (blue-red) etc. Following paragraphs will unveil the performance of few natural dyes in dye-sensitized solar cells.

\section{Mango stein Pericarp}

C. I. F. Attanayake et al. [10] have declared dye extract of mangostein pericarp as best dye out of 100 natural dyes and its performance parameters are $\mathrm{J}_{\mathrm{sc}}=2.56 \mathrm{~mA} / \mathrm{cm}^{2}, \mathrm{~V}_{\mathrm{oc}}=685.3 \mathrm{mV}$, $\mathrm{FF}=60.02 \%, \eta=1.053 \%$. These parameters quantify comparable to the output of DSSC assembled by using anatase $\mathrm{TiO}_{2}$ with N719 dye. Experimented with 20 natural dyes as sensitizers and quoted highest efficiency of mangostein pericarp [11]. Its output is $\mathrm{J}_{\mathrm{sc}}=2.69 \mathrm{~mA} / \mathrm{cm}^{2}, \mathrm{Voc}=686 \mathrm{mV}, \mathrm{FF}=63.3 \%, \eta=1.17 \mathrm{~s} \%$. They compared different xanthone components of same dye (Mangostein pericarp) and found that Rutin was most effectual.

\section{Lawsonia Inermis (Henna)}

In Henna, color causing agent is laws one, (2-hydroxy-1, 4-naphthoquinone) also known as hennotannic acid, $\mathrm{C}_{10} \mathrm{H}_{6} \mathrm{O}_{3}$, a burgundy organic compound that shows an affinity for bonding with protein as quoted its performance parameters $\mathrm{J}_{\mathrm{sc}}=0.9 \mathrm{~mA} /$ $\mathrm{cm}^{2}$, Voc $=1.3 \mathrm{~V}, \mathrm{FF}=93 \%, \eta=1.1 \%$ [12]. The solar cells synthesized using TiO2 photo anode sensitized using dye extract with $\mathrm{pH}$ values low, high and higher show efficiency values of $1.04 \%$, $1.21 \%, 1.06 \%$ respectively. This data clearly indicates that by optimizing $\mathrm{pH}$ value efficiency can be controlled and a suitable value of acidity leads to an increment in the efficiency of a DSSC. Lawson Inermis can also be experimented to get high output by changing extracting temperature as reported by Sakhtivel et al [12]. According to Sakhtivel Henna showed highest efficiency in DSSC at a temperature 750C out of three working temperatures viz. 500C, $750 \mathrm{C}$ and 1000C. We can say that solvent, $\mathrm{pH}$ and extraction temperature are the keys to open the locks of high output, if explored in a right direction.

\section{Fire fern}

Oxalis hedysaroides is popularly known as fire fern; a flowering perennial plant. Its leaves are green in color but turn deep purple red due to exposure to sun. Oxalis hedysaroides is a very mobile plant and rotates its foliage significantly to follow the sun. Ivan et al. has observed that it shows absorption in a wide range 200-600 nm. If fire fern is used in acidic medium $(\mathrm{HCl})$, its absorption range remains same but intensity of peaks increases appreciably. Experimented with co- sensitization of fire fern with dye obtained from begonia black velvet onto layer of $\mathrm{TiO}_{2}$ photo anode. Combination of these dyes give better results as both are anthocyanins. Co-sensitized cell showed conversion efficiency $\eta=1.2 \%$ and $\mathrm{J}_{\mathrm{sc}}=5.08 \mathrm{~mA} / \mathrm{cm}^{2}$, Voc $=4.129 \mathrm{~V}, \mathrm{FF}=57.2 \%$ while individual devices made from fire fern $(\eta=0.96 \%)$ and begonia black velvet $(\eta=0.87 \%)$ are quite lesser efficient [13].

\section{Turmeric}

Turmeric is a rhizomatous herbaceous perennial plant of ginger family. It shows absorption in 200-500 nm but when used with $\mathrm{HCl}$, range remains same and intensity increases. Voc $=600$ $\mathrm{mV}$ [14] have observed the effect of $\mathrm{pH}$ on photosensitization of Curcuma longa L. (turmeric) by using $\mathrm{HCl}, \mathrm{HNO}_{3}$ and $\mathrm{CH}_{3} \mathrm{COOH}$ in DSSC. They unveiled, although stronger acid increases the absorption intensity of turmeric yet it may etch the semiconductor surface and thereby decreasing output. In their experiments acetic acid was effectual to improve performance. This concludes that the acidic medium is favourable for an efficient DSSC with turmeric as dye.

\section{Beetroot}

Beta Vulgaris (beetroot) contains betalain dye that covers whole of the visible spectrum in its absorption range but highest intensity is observed in green band. Bhanushali and co-workers studied the performance of dye-sensitized solar cells using beta vulgaris (beet root) at different value of $\mathrm{pH}$, temperatures and solvents [15]. Comparison of $\mathrm{pH}$ values showed that the more acidic the medium is the more is efficiency. It was found that 500C temperature was best suited for their task. Bhanushali declared ethanol as the best solvent to be used with beetroot. His group reported $0.69 \%$ efficiency of DSSC in their working conditions.

\section{Conclusion}

Various dyes have been explored as sensitizers in dyesensitized solar cells. If natural dyes are used in dye-sensitized solar cells then we can assert that we are getting a clean, cost effective and environment friendly energy. There exist a lot of dyes performing hopefully in DSSC viz. mangostein pericarp, turmeric, beet root, fire fern, maharanga bi color herb, rose Bengal etc. We have found highest output in case of rose Bengal dye used by They calculated an efficiency value of 2.09\% [16]. Our group's previous studies have shown that efficiency of $\mathrm{TiO}_{2}$ as photo anode has been significantly raised by modifying its morphology and keeping the dye same [17]. It is possible 
that same hierarchy may lead to an enhanced performance of DSSC with natural dyes and then we will be able to meet the fundamental aim of DSSC technology that is an optimized cost to performance ratio.

\section{References}

1. West (1974), "Proceedings of vogel centennial symposium," Photographic Science and Engineering p. 18-35.

2. E R Becquerel (1960), “ photovoltaic effect in binary compounds," ] Chem Phys 32: 1505-1514.

3. D M Chapin, Fuller G L, Pearson (1954) "A new silicon p-n junction photocell for converting solar radiation into electrical power," J Appl Phys 25(5): 676-677.

4. B O’Reagan, Gratzel (1991) “A low-cost, high-efficiency solar cell based on dye-sensitized colloidal $\mathrm{TiO}_{2}$ films," Nature 353: 737-740.

5. Y L Lee, C F Chi, S Y Liau, " CdS/CdSe Co-Sensitized $\mathrm{TiO}_{2}$ Photo electrode for Efficient Hydrogen Generation in a Photo electrochemical Cell," Chem Mater 22(3): 922-92.

6. J Bisquert FF, Santiago J M, Sero GG (2009) "Electron life-time in dye sensitized solar cells: Theory and Interpretation of Measurements," Journal of physical chemistry C 113(40): 17278-17290.

7. J N Clifford, E Palo mares M K, Nazirudin M, Gratzel (2007) “Dye dependent regeneration mechanism in dye sensitized nanocrystalline solar cells," Phys Chem C 111(17): 6561-6567.

8. F Zhang R, Lynden-Bell (2005) "Interactions of tri iodide cluster ion with solvents," Eur Phys J D 34(4): 129-132.

9. Stefan Haid, Magdalena Marszalek, Amaresh Mishra

(2012)
"Significant Improvement of Dye-Sensitized Solar Cell Performance by Small Structural Modification in $\pi$-Conjugated Donor-Acceptor Dyes," Advenced Functinal Materials 22(6): 1291-1302.

10. Attanayake C, De Silva (2011) "Dye-sensitized solar cells using 20 natural dyes as sensitizers," Journal of Photochemistry and Photobiology A: Chemistry 219: 188-194.

11. S Sakhtivel, Baskaran (2013) "Thin film photovoltaic systems using natural dyes," Nano Vision 5 (7): 185-190.

12. RE Rathnasekara Dissanayaka, Senadeera, (2015)“A double layered co-sensitization in dye sensitized solar cells (DSSCs) by using natural pigments," Sri Lanka Association for the Advancement of Science Proceedings of the $71^{\text {st }}$ Annual Sessions p. 33

13. Hee-Je-Kim, Kyoung-Ok Min, Jung-Hyun Choi (2015) "Potential of purple cabbage, coffee, blueberry and turmeric as natural dyes for dyesensitized solar cells," Energy Procedia 79(5): 799-807.

14. Aakash Umesh Bhanushali, Pratibha Nalini (2010) "Potential development in natural dyes based dye-sensitized solar cells," Progress in heterocyclic chemistry 5(4): 234-237.

15. Roy P, Balraju M, Kumar GD (2008) Dye-sensitized solar cell based on Rose Bengal dye and nanocrystalline $\mathrm{TiO}_{2}$ Sol Energ Mat Sol C 92: 909913.

16. Jyoti D, Mohan, Dhar (2013) Investigation of the opulent porosity for better performance of dye-sensitized solar cell, Journal of Renewable and Sustainable Energy 5: 013112-013114.

17. Jyoti D, Mohan, Dhar , Purnima (2011) Influence of electrode thickness on the performance of dye-sensitized solar cells, Invertis Journal of Renewable Energy 1(2): 108-114.

\section{Your next submission with Juniper Publishers will reach you the below assets}

- Quality Editorial service

- Swift Peer Review

- Reprints availability

- E-prints Service

- Manuscript Podcast for convenient understanding

- Global attainment for your research

- Manuscript accessibility in different formats ( Pdf, E-pub, Full Text, Audio)

- Unceasing customer service

Track the below URL for one-step submission https://juniperpublishers.com/online-submission.php 